\title{
COVID-19: Neurological Considerations in Neonates and Children
}

\author{
Carl E. Stafstrom ${ }^{1, *}$ and Lauren L. Jantzie ${ }^{2}$ \\ 1 Division of Pediatric Neurology, Departments of Neurology and Pediatrics, The Johns Hopkins University \\ Hospital and School of Medicine, Baltimore, MD 21287, USA \\ 2 Departments of Pediatrics, Neurosurgery, and Neurology, The Johns Hopkins University Hospital \\ and School of Medicine, Baltimore, MD 21287, USA; LJantzie@jhmi.edu \\ * Correspondence: cstafst1@jhmi.edu; Tel.: +1-410-955-4259
}

Received: 30 July 2020; Accepted: 1 September 2020; Published: 10 September 2020

check for updates

\begin{abstract}
The ongoing worldwide pandemic of the novel human coronavirus SARS-CoV-2 and the ensuing disease, COVID-19, has presented enormous and unprecedented challenges for all medical specialists. However, to date, children, especially neonates, have been relatively spared from the devastating consequences of this infection. Neurologic involvement is being increasingly recognized among adults with COVID-19, who can develop sensory deficits in smell and taste, delirium, encephalopathy, headaches, strokes, and peripheral nervous system disorders. Among neonates and children, COVID-19-associated neurological manifestations have been relatively rare, yet reports involving neurologic dysfunction in this age range are increasing. As discussed in this review, pediatric neurologists and other pediatric specialists should be alert to potential neurological involvement by this virus, which might have neuroinvasive capability and carry long-term neuropsychiatric and medical consequences.
\end{abstract}

Keywords: COVID-19; coronavirus; SARS-CoV-2; neonate; neurological; brain; neurotropism; cytokine storm; neuroinflammation; neurodevelopment

\section{Introduction}

Severe and at times fatal symptoms caused by the novel human coronavirus, Severe Acute Respiratory Syndrome (SARS)-CoV-2, and the associated coronavirus disease 2019 (COVID-19), are ravaging the world. While symptoms of COVID-19 are primarily pulmonary (fever, dry cough, fatigue, pneumonia), it is becoming increasingly recognized that multiple organ systems can be affected, including the brain, with neurological involvement affecting up to $36 \%$ of patients [1-5]. Information gained from studies of related coronaviruses in recent epidemics of Severe Acute Respiratory Syndrome (SARS, 2002) and Middle East Respiratory Syndrome (MERS, 2012) suggests that all three coronaviruses might have neurologic consequences [6,7], though the relative severity and frequency of neurologic involvement caused by coronaviruses varies and thus the extent to which SARS and MERS epidemics inform our understanding of COVID-19 remains unclear [5]. Nevertheless, the possibility has been raised that SARS-CoV-2 could invade the brain and cause neurological disease [2,8]. While appealing conceptually, data supporting the idea that the SARS-CoV-2 virus can infect the peripheral and central nervous systems (PNS, CNS) are limited, as discussed below. Table 1 lists definitions of relevant terms that are often used in the literature. Neurotropic viruses vary in their invasiveness, virulence, and propensity to cause inflammation [9]. 
Table 1. Definitions relevant to viral infections of the peripheral and central nervous systems.

\begin{tabular}{ll}
\hline Neuroinvasive & Virus is capable of accessing and entering the nervous system \\
\hline Neurotropic & Virus is capable of infecting nerve cells once in the nervous system \\
\hline Neurovirulent & Neurotropic virus is capable of causing disease in the nervous system \\
\hline Neuroinflammatory & $\begin{array}{l}\text { Virus causes secondary inflammatory response within the nervous } \\
\text { system }\end{array}$ \\
\hline
\end{tabular}

The purpose of this review is twofold: (1) to discuss the available data about COVID-19 infections in neonates and children, and (2) to provide a perspective about potential neurologic involvement in neonates and children with COVID-19 infections, in view of neurobiological development.

A few points need clarification up front. First, data about the virus and its effects are accumulating rapidly and our understanding of its consequences will evolve over time. Second, much of the literature about COVID-19 currently exists as case reports or small series; obviously, the impact of such publications is limited, and greater understanding will emerge only as large, rigorous studies are published. Third, we must be mindful that a positive test for SARS-CoV-2 in a patient with a neurological symptom does not necessarily imply that the virus caused the symptom.

\section{COVID-19 in Neonates and Children}

The COVID-19 epidemic has escalated rapidly and spread widely across the globe, with cases continuing to accrue at an alarming rate. The first case was reported from Wuhan, China in mid-December 2019 and three months later, in March 2020, the World Health Organization declared COVID-19 a pandemic. As of this writing (late August, 2020), more than 23 million cases of COVID-19 have been documented worldwide (with many more mildly symptomatic cases likely not reported), with over 800,000 deaths, and more than 175,000 deaths in the United States alone (www.cdc.gov, accessed 24 August 2020).

Documentation of the numerous clinical presentations, manifestations, and disease course have proliferated in the medical literature. A PubMed search (23 July 2020) using the keyword COVID-19 revealed an astounding number of published reports already $(34,310)$, over the course of only a few months. Of those citations, only 501 reports $(1.5 \%)$ also included the keyword neonate, attesting to the low published incidence in newborns. When searching PubMed with the key terms COVID-19, neonate and neurological or brain, fewer than 10 articles emerged. Therefore, at least so far, COVID-19 does not seem to be affecting neonates very often from a neurological point of view; PubMed counts probably underestimate the occurrence of neurological involvement in children, being biased toward areas of the world with greater medical resources. These observations do not preclude the potential for neonatal brain involvement in COVID-19 nor exclude the possibility of long-term medical, neurodevelopmental, and psychosocial consequences of the disease. Indeed, as time goes on, a wider spectrum of neurologic manifestations will likely emerge with as yet undetermined long-term sequelae.

As the COVID-19 pandemic continues, certain trends are becoming evident. First, while the number of cases and deaths continue to rise, the disease does not affect infants and children nearly as frequently as adults $[9,10]$. To date, approximately $2-5 \%$ of cases of COVID-19 involve children, who appear to be less severely affected than adults, mainly with pulmonary symptoms [11-13]. Second, disease severity in children who develop COVID-19 is usually milder than in adults, and children with severe disease often have an underlying co-morbidity such as immunosuppression [10,14]. Indeed, there is accumulating evidence that adults with COVID-19 infection manifest with multiple organ system involvement, including the CNS and PNS, and that older and sicker individuals carry a higher risk for neurologic problems $[1,4,15]$. These age-dependent differences in disease expression and severity have clear implications for healthcare professionals who deal with the pediatric population because children remain at risk for incurring and spreading the virus, yet many remain asymptomatic. Several hypotheses have been posited as to why children are less affected by COVID-19, including age-related differences 
in immune responses [16], a neutralizing antibody response due to prior exposure to coronaviruses [17], lower prevalence of co-morbidities in children, and age-specific differences in SARS-CoV-2 receptor function [18], neurovirulence, intrinsic biological protective mechanisms, and other host factors [19]. None of these hypotheses is supported compellingly by extant data at present.

While the number of affected neonates and children remains small, pediatric practitioners cannot become complacent about the potential for neurologic involvement in COVID-19. Furthermore, the recently described multisystem inflammatory syndrome-children (MIS-C), raises the specter that COVID-19 or its after-effects also target children (see Section 4) [20,21]. As data from China, Europe and other areas affected early by the COVID-19 pandemic are reported, some patterns are emerging regarding pregnant women and neonates. First, it is clear that vertical transmission COVID-19 from a pregnant mother to her fetus occurs quite rarely. More than a dozen publications attest to this observation, together encompassing over 100 patients (Table 2 lists a few relevant publications, selected from the largest available series and omitting small series and single case reports). None of these reports documents unequivocal vertical transmission. In many of the babies, onset of symptoms occurred in the neonatal period but not immediately at birth, so the exact timing of infection remains uncertain. Overall, the data does not support robust transplacental transfer of SARS-CoV-2, but recent case reports are providing proof-of-principle that the virus can be transmitted intrauterine from infected mother to fetus [22,23]. An especially apropos case demonstrated maternal viremia, placental infection shown by immunohistochemistry, and high placental viral load with subsequent neonatal viremia, implying transplacental transfer of SARS-CoV-2 from pregnant mother to fetus [24]; this newborn presented with neurological symptoms as discussed in Section 3.

Table 2. Selected reports evaluating potential vertical transmission of SARS-CoV-2.

\begin{tabular}{lccl}
\hline \multicolumn{1}{c}{ Publication } & Newborns (n) & SARS-CoV-2 Positive (n) & \multicolumn{1}{c}{ Comments } \\
\hline Chen et al. 2020 [25] & 9 & 0 & All C-sections \\
\hline Zhang et al. 2020 [26] & 16 & 0 & $\begin{array}{l}\text { All C-sections; same institution } \\
\text { as Chen et al. 2020 [25] }\end{array}$ \\
\hline Zeng et al. 2020 [27] & 33 & 3 & $\begin{array}{l}\text { Tested 2-3 days postpartum; } \\
\text { two full terms and one 31-wga } \\
\text { premature infant; all developed } \\
\text { pneumonia but recovered by } \\
\text { 1-2 weeks of life }\end{array}$ \\
\hline Liu et al. 2020 [28] & 19 & 0 & $\begin{array}{l}\text { PCR negative on body fluids * } \\
\text { None developed symptoms }\end{array}$ \\
\hline Schwartz et al. 2020 [29] & 38 & & $\begin{array}{l}\text { "No evidence that SARS-CoV-2 } \\
\text { undergoes intrauterine or } \\
\text { transplacental transmission } \\
\text { from infected pregnant women } \\
\text { to their fetuses." }\end{array}$ \\
\hline Lu \& Shi 2020 [30] & & 0 & $\begin{array}{l}\text { 3 cases mentioned; diagnosed } \\
\text { 2-17 DOL. Details sparse }\end{array}$ \\
\hline Salvatore et al. 2020 [31] & $\begin{array}{l}\text { 120 (DOL 1) } \\
72 \text { (DOL 5-7) }\end{array}$ & 3 & $\begin{array}{l}\text { Cohort of infants born to } \\
\text { SARS-CoV-2 mothers, followed } \\
\text { through 2 weeks of life }\end{array}$ \\
\hline
\end{tabular}

Abbreviations: C-sections, Caesarean sections; PCR, polymerase chain reaction; wga, weeks gestational age; DOL, day of life * nasopharyngeal fluid, urine, feces, breast milk, amniotic fluid.

Of all the infants reported during the first month of life, most had documented exposure to affected family members $[13,32]$ which emphasizes the importance of controlling horizontal virus transmission from affected family members to the neonate [33]. While this trend may need revision [27,34], so far, it is encouraging that most COVID-19-positive pregnant women do not transmit the disease to their unborn children. Similarly, there is no evidence that COVID-19-positive pregnant women incur 
COVID-19 or develop more severe disease than similar-aged women who are not pregnant. However, the impact of chronic inflammation caused by maternal viral infection on fetal development, pregnancy outcomes and long-term neurodevelopment is unknown. Similarly, the timing of maternal viral infection with respect to major milestones of in utero neurodevelopment (i.e., second trimester vs. late third trimester) is an unknown and critical consideration for further research and long-term neurodevelopmental followup. There is legitimate concern about the impact of acute and chronic stress during the pandemic (i.e., worry about the medical complications of SARS-CoV-2 infection, family disruption, job loss, economic pressures, educational uncertainties, food availability, etc.) on the pregnant patient and developing fetus [35-38].

Furthermore, it is reassuring that there is no definitive evidence that the virus is present or can be transmitted in the breast milk of COVID-19-positive women [28,39,40]. The current American Academy of Pediatrics recommendation is that COVID-19-positive mothers can breast feed directly while wearing a mask or feed expressed breast milk, using appropriate breast and hand hygiene [41]. Extensive guidelines are available regarding principles of management of pregnant women with COVID-19 and their newborns [40-42]. Again, all of these observations are preliminary and subject to modification over time.

\section{Neurological Involvement in COVID-19}

Although COVID-19 primarily affects the pulmonary system, it is a multisystem infection (e.g., gastrointestinal tract, kidneys, liver, heart) and involvement of the PNS and CNS are increasingly recognized [43-46]. Data on neurological signs and symptoms are limited but increasing, with a wide spectrum of acute and chronic manifestations becoming apparent [47]. In a series of 214 hospitalized adults with COVID-19, 88 of whom had "severe" infections, $36.4 \%$ of the entire group was reported to manifest some neurologic involvement, including alteration of consciousness, encephalopathy, headache, cerebrovascular disease, and skeletal muscle injury (myalgia, weakness) [1].

\subsection{Cerebrovascular Disease}

Ischemic strokes, many affecting young adults with large vessel occlusions, have garnered considerable concern that the etiology may be a prothrombotic state caused by virus-induced inflammation of the vascular epithelium [48,49]. Many of the young adult stroke victims had other vascular risk factors such as diabetes or hypertension, which emphasizes the importance of comorbidities with systemic inflammatory conditions in disease manifestations and severity. Stroke has not been reported in children with COVID-19 [50].

\subsection{Encephalitis}

The occurrence of encephalitis remains controversial, as virus has not been recovered from cerebrospinal fluid (CSF) [51] and overall, a surprisingly small number of COVID-19 patients develop classic encephalitic symptoms. Autopsy studies are beginning to be published. The wide spectrum of postmortem findings include mostly secondary changes to the CNS such as hypoxemia and ischemia, rarely localized perivascular and interstitial neuroglial activation with neuronal loss and axonal degeneration [52,53], and no other major CNS abnormalities [54]. No pediatric autopsy cases have reported neuropathological involvement. Clearly, more data are needed before this issue can be clarified.

\subsection{Seizures and Other CNS Symptoms}

In the Chinese series [1], only 2 out of 214 patients had seizures (1\%), which is not greater than the general population, so it is uncertain whether infected patients are at higher risk. The few patients with seizures are reported mainly in case reports $[55,56]$. The lack of frequent seizures is rather curious, especially if encephalopathy is indeed a frequent complication of COVID-19; this data may be related to sampling bias rather than actual non-occurrence. A few reports of seizures have appeared in adults using electroencephalography (EEG) $[57,58]$, but a more concerted effort to evaluate the brain 
electrophysiology of children with COVID-19 would be informative. The examples of seizures in children with COVID-19 described in Section 3.6 appear to be largely anecdotal. Many additional cases are necessary to conclude whether there is increased seizure susceptibility in the pediatric population.

Other CNS symptoms include headache, dizziness and delirium, all of which can occur as a nonspecific consequence of systemic infection or inflammation of the respiratory tract as well as via a CNS mechanism. Although headaches are reported frequently, the pain often appears to be nonspecific or associated with inflammation or migraine exacerbation rather than meningeal irritation [59].

\subsection{Hypogeusia, Hyposmia}

The most commonly reported symptoms related to the PNS are decreased taste (hypogeusia or ageusia) and smell (hyposmia or anosmia) [60,61]. A neural mechanism is suspected for hyposmia in COVID-19, because decreased smell is often the first symptom experienced and occurs in mild disease in the absence of significant local inflammation or mucosal congestion that are typical of the more benign coronavirus or non-coronavirus nasal infections [62]. A few adolescents with COVID-19 have been reported with decreased taste or smell [63]; these symptoms appear to be very uncommon in children but deserve a more concerted ascertainment effort.

\subsection{Demyelinating Disorders}

Several cases of Guillain-Barré syndrome (GBS) have been reported in adults with COVID-19, raising the possibility of post-infectious autoimmune responses against the PNS [64,65]. Two case reports of children with GBS who developed COVID-19 symptoms about 3 weeks later confirms that GBS can occur with COVID-19, though this association remains quite rare given the widespread prevalence of COVID-19 [66,67]. Finally, the possibility of central demyelination has been raised, e.g., in the form of multiple sclerosis (MS), among patients with COVID-19 [68]; this concern is relevant in that various disease-modifying agents used to treat MS could theoretically exacerbate MS symptoms [69]. Fortunately, there is no evidence that COVID-19 triggers central demyelinating disease in children [50].

The lack of unequivocal reports of SARS-CoV-2 being recovered from the CSF of individuals affected with presumed neurological involvement nor in brain tissue from the limited number of autopsied cases strengthens the possibility that the virus does not often directly cause the symptoms but rather, that the neurological sequelae are secondary to hypoxia, cytokine involvement, or some other non-direct mechanism (see Section 6). It is appropriately concerning that chronic neurologic diseases such as epilepsy, amyotrophic lateral sclerosis, multiple sclerosis, etc., might be exacerbated during concurrent COVID-19 infection or that COVID-19 may unmask preexisting CNS pathology that might have been unrecognized or asymptomatic.

\subsection{Examples of Children with Neurological Involvement}

As just discussed, neurologic involvement in children, and in particular neonates, with COVID-19 appears to be scarce but may be under reported [70]. A few selected examples of case reports of neurologic involvement in neonates and children are presented in Table 3; such case reports have limited generalizability, and many lack sufficient details to ascribe causality between SARS-CoV-2 and neurologic symptoms. Most children were assumed to have contracted COVID-19 from a family member and some children had concurrent infection with other viruses, confounding any argument for causality. Importantly, CSF was negative for SARS-CoV-2 in all children on whom spinal fluid was obtained. All children recovered within a few days or weeks, contrasting with the severe and prolonged courses in many adults. Available evidence does not allow distinction between a direct effect of SARS-CoV-2 causing neurologic dysfunction, versus the symptoms instead being secondary to an over activated immune response (see Section 5). In summary, case reports of neurological involvement in babies and children are rare but accumulating, and the recovery of most infants with 
early neurologic symptoms implicates some virus- or host-related factors that minimize massive neurological devastation.

Table 3. Selected case reports of COVID-19 neurologic involvement in neonates and children.

\begin{tabular}{cccccc}
\hline Neonates (n) & Age & Presenting Symptoms & SARS-CoV-2 Testing & SARS-CoV-2 CSF & Reference \\
\hline 5 & $<3 \mathrm{y}$ & Hypotonia, drowsiness & $\mathrm{NP}+$ & $4 / 4-$ & {$[71]$} \\
\hline 1 & $26 \mathrm{~d}$ & Upward eye deviation, stiffening & $\begin{array}{c}\mathrm{NP}+ \\
\text { Blood, cEEG, HUS - }\end{array}$ & $\mathrm{NR}$ & {$[72]$} \\
\hline 1 & $1 \mathrm{~d}$ & Lethargy, encephalopathy & $\mathrm{NP}+$, rectal + & - & {$[73]$} \\
\hline 1 & $6 \mathrm{w}$ & Upward eye deviation, leg stiffening & $\mathrm{NP}+$ & - & {$[74]$} \\
\hline 1 & $11 \mathrm{y}$ & Seizure & $\mathrm{NP}+$ & $\mathrm{NR}$ & {$[75]$} \\
\hline 1 & 3d & Irritability, hypertonia & $\begin{array}{c}\text { Brain MRI + (transient } \\
\text { gliosis of periventricular } \\
\text { white matter } \\
\text { and subcortical structures) }\end{array}$ & & {$[24]$}
\end{tabular}

Abbreviation: y, years; d, days; w, weeks; NP, nasopharyngeal; cEEG, continuous electroencephalography; HUS, head ultrasound; MRI, magnetic resonance imaging; NR, not reported; +, positive; -, negative.

\section{Neurological Signs and Symptoms in Multi-System Inflammatory Syndrome (MIS-C)}

This newly recognized Kawasaki syndrome-like hyperinflammatory disorder presents with acute hypotension and cardiogenic shock and is proliferating across the globe. It is likely a post-infectious syndrome or inflammatory reaction following asymptomatic or mildly symptomatic COVID-19 [76]. Children can develop toxic shock-like symptoms, hypoxia-ischemia, and significant end organ damage to the heart, kidneys, and other organs. While definitive data is not available, there is concern that the inflammation that hallmarks MIS-C may have adverse consequences on the developing brain. While no consistent neurologic picture has emerged, several MIS-C patients have had CNS involvement as part of their course. In a small series of 6 children with MIS-C, 4 patients had neurologic symptoms, including headache, altered mental status, and aseptic meningitis [77]. Headache was the most common symptom in a series of 58 children with MIS-C associated with SARS-CoV-2, affecting $26 \%$ of patients [78]. A series 21 children from France notes that $57 \%$ of patients were "irritable" and another $29 \%$ had "other neurological features", though these were not specified [79]. In a larger survey of 186 children, $5-11 \%$ had neurologic involvement, depending on age, including encephalitis, seizures or mental status alteration, but details are not provided [80]. Finally, 4 of 27 children with COVID-19 associated MIS-C developed new neurologic symptoms including encephalopathy, headache, weakness, ataxia, and dysarthria [81]; two patients had lumbar punctures and CSF was negative for SARS-CoV-2 in both. Three of the four patients had an EEG; each showed diffuse slowing. Brain MRI scans of all four children showed abnormal signal intensities of the splenium of the corpus callosum (a finding seen in previous cases of encephalopathy and thought to indicate inflammation-induced focal myelin edema [81,82]. A recent systematic review of eight studies notes neurological symptoms in $\sim 25-50 \%$ of children with MIS-C, depending upon inclusion criteria [83]. A putative impact on the immature CNS and developing immune system, including neural-immune maturation, cannot be overlooked, and the long-term neurologic impact of both COVID-19 and MIS-C on the developing brain need urgent elucidation.

\section{Coronavirus Infectivity}

SARS-CoV-2 is a highly contagious and pathogenic RNA virus that is transmitted via droplet, contact, or aerosol routes. The virus gains entry into epithelia of the pulmonary system (upper or lower respiratory tracts), digestive tract, or nasopharynx. The virus is composed of single-stranded RNA enveloped by surface proteins ( $, E, M, N)$. The spike (S) glycoprotein serves as the attachment site onto angiotensin converting enzyme type 2 (ACE-2) receptors on epithelial membranes. The normal function of ACE-2 receptors is to provide protection against pulmonary and endothelial injury [84]. SARS and SARS-CoV-2 share $~ 79 \%$ genome sequence identity and both viruses infect epithelium by 
the binding of spike proteins to ACE-2 receptors. While most prevalent on airway and pulmonary epithelium [85], ACE-2 receptors are also reportedly present to a lesser degree on neurons and perhaps glia [2].

Binding of the S protein to ACE-2 receptors leads to proteolytic cleavage of $S$ by the transmembrane protease TMPRSS2 [5]. Viral RNA then enters the epithelial cell and replicates rapidly, translating viral proteins and inducing a host immune response. This immune response can be adaptive, attacking and inactivating the virus. By contrast, the immune response can be maladaptive and induce a massive immune reaction, accompanied by a hyper-inflammatory response hallmarked by excessive cytokine secretion and signal transduction (cytokine storm), and robust cellular immune activation and recruitment [86]. The large-scale cytokine storm consists of a massive release of pro-inflammatory humoral agents such as interleukin-6 (IL-6), interferon gamma (IFN-Y), MCP-1/CCL2 (monocyte chemoattractant protein 1/chemokine ligand 2), IL-1, IL-12, IL-8, TNF $\alpha$ (tumor necrosis factor alpha), and CXCL 10 (C-X-C motif chemokine ligand 10) that exacerbate the underlying pathophysiology $[87,88]$. This cytokine release subsequently feeds forward an overactive and dysregulated cellular immune response defined by macrophage, monocyte, neutrophil, and T-cell hyperactivation and recruitment [89]. The impact of this systemic cytokine storm on neurodevelopment is under investigation in preclinical models [90] and should be the focus of future prospective studies. Subsequently, the replicated viruses exit the cell, leading to further infection.

It is unknown why children, and neonates in particular, seem to be relatively resistant to COVID-19 and its severe symptoms, including neurological manifestations. The cytokine response to coronavirus infection appears to be less robust in young children although the recognition of MIS-C may suggest host-dependent genetic susceptibility to enhanced cytokine and/or inflammatory responses [91], but other mechanisms are also plausible [19]. It remains controversial whether ACE-2 inhibitors would provide symptomatic relief or prevent the COVID-19 disease, and evidence for the effectiveness of these agents in children and neonates is not yet available [92].

\section{SARS-CoV-2 Neurologic Mechanisms}

The cellular and molecular basis of SARS-CoV-2 neurotropism, neuroinvasiveness, and neurovirulence are poorly understood [9]: does the virus get into the brain and if so how, and what does it do in the CNS once there (e.g., infects neural cells? causes disease?). Neurological involvement in COVID-19 might be associated with at least four potential mechanisms: 1 . A direct neurotropic or neuroinvasive effect of SARS-CoV-2 (e.g., anosmia, encephalopathy), 2. A secondary effect of the systemic inflammatory responses triggered by the viral infection (e.g., encephalopathy), 3. A secondary effect associated with the vascular and prothrombotic effect of the viral infection on the CNS or PNS vasculature (e.g., strokes, necrotizing leukoencephalopathy), 4. An immune-mediated para-infectious or post-infectious autoimmune effect in response to the viral infection (e.g., GBS, acute disseminated encephalomyelitis). Figure 1 summarizes, in schematic fashion, some hypothetical possibilities about how the virus may infect the brain directly, whether the neurological symptoms and signs may be related to systemic or hyperactivation of immune responses, or both [87]. It is important to consider the mechanisms associated with neurological manifestations of COVID-19, with an aim toward developing therapeutic options. The possibilities of direct neurotropism and hyper-responsiveness to immune activation (cytokine storm) are considered separately below, though these mechanisms might work synergistically. 


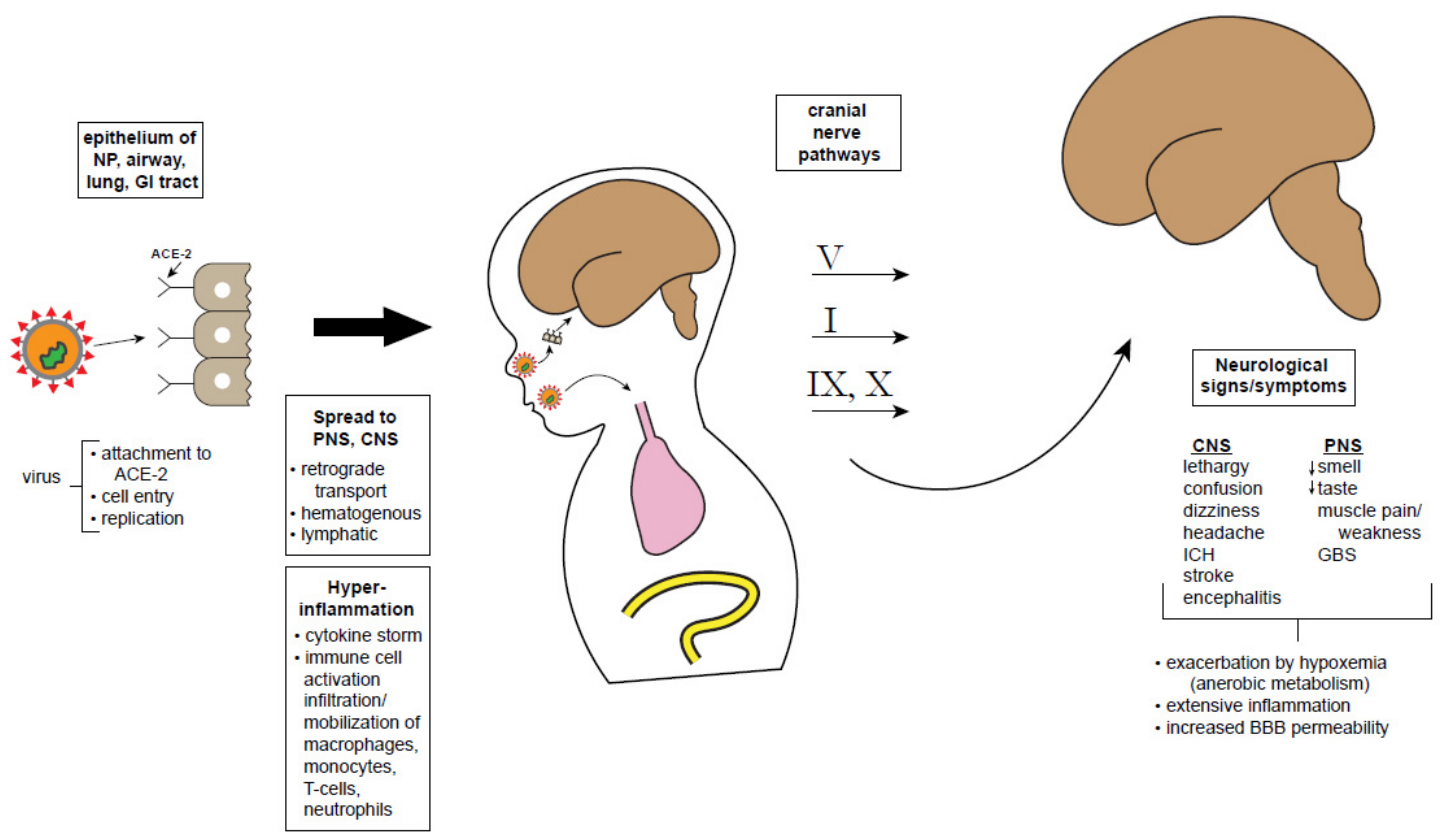

Figure 1. Schematic showing possible CNS entry points and effects of SARS-CoV-2. The SARS-CoV-2 virus attaches to olfactory epithelium using the ACE-2 receptor. After cell entry, the virus replicates and induces a massive immune response leading to excessive cytokine release, comprising a maladaptive immune response. Theoretically, virus particles may reach the CNS retrogradely via cranial nerve pathways: V from corneal epithelium or oropharyngeal cutaneous sensory receptors; I via the cribiform plate, infecting olfactory sensory neurons; VII and IX from tongue chemoreceptors; X via pulmonary mechanoreceptors. Once reaching CNS nuclei including brainstem and cortex, a variety of neurologic signs and symptoms are possible. However, it must be noted that the virus has not been recovered from CSF or brain tissue, making all of these pathways hypothetical at this point. Abbreviations: NP, nasopharynx; GI, gastrointestinal; ACE-2, angiotensin converting enzyme type 2 receptor; $\mathrm{PNS}$, peripheral nervous system; $\mathrm{CNS}$, central nervous system; $\mathrm{ICH}$, intracranial hemorrhage; GBS, Guillain-Barre syndrome; BBB, blood-brain barrier.

Definitive demonstration of direct viral invasion would require a positive CSF reverse transcriptase-polymerase chain reaction (RT-PCR) for SARS-CoV-2, recovery of infective virus from the CSF as demonstrated by viral cultures or "plaque assay" [93], intrathecal synthesis of antibodies to SARS-CoV-2, or autopsy-demonstrated SARS-CoV-2 antigen or RNA in brain tissue [5]. Current published evidence meeting these strict criteria is minimal. While it is plausible that the virus infects the brain through one of the anatomical pathways discussed below, the lack of viral recovery from the CNS gives pause to that notion. Neuroinvasion has been demonstrated for the related SARS and MERS viruses [94], but SARS-CoV-2 has not been recovered from the CSF or brain tissue. Animal models of SARS and MERS have shown that the virus can enter through epithelium of the nasopharynx and travel retrogradely to the CNS $[95,96]$. Interestingly, wild type mice are not vulnerable to infection and disease by human coronaviruses, but transgenic mice with human ACE-2 receptors do develop respiratory and neurological symptoms when infected [95,97]. In such transgenic mice, intranasal exposure to SARS or MERS leads to brain infection. One of the proposed portals of entry is via olfactory sensory neurons, crossing the cribiform plate into the olfactory bulb, with subsequent retrograde travel along the olfactory nerve (cranial nerve I) to the brainstem, thalamus, and basal ganglia, all areas that are connected to the olfactory cortex. Please note that it has yet to be proven that SARS-CoV-2 infects olfactory sensory neurons. Emerging animal models may clarify whether SARS-CoV-2 is similarly neuroinvasive as SARS and whether this isage dependent [97,98]. However, since mice are not naturally susceptible to the clinical and immunopathological manifestations of coronaviruses affecting humans, translational studies of pathogenic mechanisms and vaccine development become 
complicated. Extensive efforts to modify mice with transgenic approaches have begun to provide informative models.

As mentioned, the olfactory epithelium has been touted as a potential site of viral entry into the brain, and hence explain hyposmia [99].Detailed genetic and immunohistochemical examinations of cell types of the olfactory system reveal that ACE-2 and TMPRSS2 are present on olfactory epithelial cells (especially supporting or "sustenacular" cells) but not on olfactory sensory neurons themselves [54,85,100]. Moreover, there is some evidence of virus-induced cell death in other coronavirus infections but not yet for SARS-CoV-2 [84,101].

Likewise, the virus might enter via the sensory system of the tongue that mediates taste, with transmission via cranial nerves VII, IX, and X to the nucleus tractus solitarius, thalamus and eventually, brain. Finally, trigeminal nociceptors via cranial nerve V from either the corneal epithelium or buccal epithelium could theoretically reach the CNS. These potential pathways could explain the symptoms of hypogeusia and altered vision. However, SARS-CoV-2 has not been recovered from the brain. Transynaptic transport from lower respiratory tract mechano- and chemoreceptors to the brainstem medullary cardiorespiratory centers has been proposed as a hypothetical mechanism that could exacerbate brainstem dysfunction and perhaps even worsen respiratory effort [102]; however, this hypothesis lacks objective validation and remains controversial.

Other potential routes for virus to enter the CNS are through the bloodstream (hematogenous) or via disruption of the blood brain barrier (BBB). From the systemic circulation, the virus might travel to the cerebral circulation where it can damage capillary epithelium and access the brain. Interestingly, there is scant evidence that SARS-CoV-2 produces a significant or sustained viremia [103]. The BBB is essential for transport of molecules into the brain and exclusion of pathogens and overall maintenance of cerebral homeostasis [104]. The BBB is a dynamic structure, consisting of several cell types and proteins, each with its own maturational profile-astrocyte foot processes, pericytes, tight junction proteins, and extracellular matrix, providing structural and functional support. Virus attachment to ACE-2 receptors at the $\mathrm{BBB}$ might facilitate trafficking of the virus into the $\mathrm{CNS}$, facilitating endothelial damage and edema [89]. Notably, while the BBB is structurally complete at birth and is sufficiently functional in the neonate to provide protection against many pathogens, its full physiological maturation may take several months [105]. In the context of COVID-19 infection, the BBB may be dysfunctional, disrupted either by inflammatory response or the virus itself, allowing transmission of the virus or activated immune cells from the circulation into the CNS [8,84]. The release of inflammatory cytokines by activated glia and neural mast cells exacerbate the inflammation [89]. Similarly, flow of the virus through lymphatic channels of the interstitial space of the brain could breach the blood-CSF barrier and permit virus entry [106]. To date, there is no evidence for the presence of the virus in pathological specimens of the PNS or CNS, in part due to the dearth of comprehensive autopsies [52-54]. Obviously, patient care has focused on critical pulmonary and life-support measures so neuropathologically-focused autopsy studies have been uncommon.

Animal studies of COVID-19 will be crucial to complement information gained from prior studies of the other coronaviruses. Such animal models will provide more information about mechanisms of virus entry into the nervous system and how the virus affects neural function, neural-immune maturation and neurodevelopment, as well as the critical and yet unanswered question of long-term neurological sequelae of COVID-19 [107]. That is, if there is predilection of the virus for certain neural structures or chronic neuroinflammation, long-term consequences may arise in various neural functions such as learning, memory, cognition, seizure predisposition, and other functions. All of this is speculative at present. Another essential question, alluded to above, is whether CNS disease contributes to the respiratory failure seen in COVID-19 patients. Ongoing or severe hypoxia can exacerbate ongoing symptoms in other organs. In particular, CNS respiratory control centers in the brain stem, nearby the vagus nerve, has been speculated to play a role in respiratory failure $[102,108]$. 


\section{Conclusions-A Cautionary Tale}

At present, there is some reason for guarded optimism for young patients within the devastating COVID-19 pandemic. Children, particularly neonates, are less likely to become infected and develop severe symptoms, and their propensity to spread the virus is controversial [109]. There is at best slight evidence for vertical transmission of SARS-CoV-2 or COVID-19 disease from pregnant mother to fetus; rather, neonates are more likely incur the disease by exposure to affected individuals postnatally, and breast milk transmission has not been shown (Table 4). A variety of practical guidelines have been developed for the care of pregnant women who have or are suspected to have COVID-19 positivity. Analogous guidelines for the care of adult COVID-19 patients with neurologic problems are also available and need to be developed for children [110].

Table 4. Summary of COVID-19 infections in children.

\begin{tabular}{|c|}
\hline $\begin{array}{l}\text { Severe infection caused by the novel coronavirus, SARS-Cov-2, has predominant pulmonary involvement but } \\
\text { can also affect multiple other organ systems, including the CNS and PNS. }\end{array}$ \\
\hline Symptoms are less frequent and usually less severe in children and particularly in neonates. \\
\hline $\begin{array}{l}\text { Vertical transmission of SARS-CoV-2 from pregnant mother to fetus is rare but anecdotal case reports support } \\
\text { this possibility. }\end{array}$ \\
\hline Most cases of COVID-19 in early life are due to exposures to infected patients (horizontal transmission). \\
\hline There is no reported transmission of SARS-CoV-2 via breast milk. \\
\hline
\end{tabular}

Regarding neurologic involvement in COVID-19, there are plausible mechanisms by which the virus can gain entry into the CNS and subsequently incur acute neurologic symptoms, either directly or through immune dysfunction (Table 5). The occurrence of long-term medical and neuropsychiatric sequelae is unknown. Children can be resilient and yet remain vulnerable to coping with the challenges of COVID-19 in the context of other acute and chronic diseases. Youngsters may not understand the need for social distancing, prolonged quarantine, and other preventative measures, and it is anticipated that stress-related post-traumatic symptoms will develop in some young people, whether or not they actually acquire symptoms. In children with comorbid chronic conditions and developmental disabilities, the challenges are even more profound. Therefore, neuropsychological surveillance and studies of the long-lasting effects of this pandemic on neurodevelopment are critical [111]. Finally, the emergence of the hyper-inflammatory multisystem syndrome (MIS-C) supplants any conclusion that COVID-19 is benign or negligible in the pediatric age range. Therefore, it behooves neurologists and other pediatric specialists who deal with neonates and young children to be aware of the potential neurologic involvement of this novel, potentially devastating virus. Future animal models should evaluate the impact of SARS-CoV-2 on maternal infection, inflammatory signal transduction through the maternal-placental-fetal axis, and brain development. The importance of large-scale immunization should a vaccine become available, cannot be over emphasized as should the role of systemic inflammation, neuroinflammation, and neural-immune interactions in novel pathophysiology and symptomology. Additionally, mechanism-specific targeted therapies could emerge from basic science studies of SARS-CoV-2 infection.

Table 5. Neurological involvement in COVID-19.

\begin{tabular}{c}
$\begin{array}{c}\text { Acute neurological involvement in adults with COVID-19 can include decrease taste/smell, headache, } \\
\text { confusion, peripheral nerve dysfunction, strokes, and encephalopathy. }\end{array}$ \\
\hline $\begin{array}{c}\text { Neurological involvement of COVID-19 in neonates and children is still quite rare but recent case reports } \\
\text { warrant vigilant surveillance. }\end{array}$ \\
\hline Neurological involvement of COVID-19 in neonates and children is still quite rare but recent case reports \\
warrant vigilant surveillance.
\end{tabular}


Author Contributions: C.E.S. conceptualized the article; both authors participated in its writing and final approval. All authors have read and agreed to the published version of the manuscript.

Funding: This manuscript involved no external funding.

Acknowledgments: Research in the laboratory of Stafstrom is supported by the Mathias Koch Memorial Fund, the Sandra and Malcolm Berman Foundation, and the Paine Foundation. Research in the laboratory of Jantzie is supported by the National Institutes of Health (1R01HL139492) and the Department of Defense (W81XWH-18-1-0167). We thank Carlos Pardo-Villamizar for his insightful comments and critique of the manuscript.

Conflicts of Interest: The authors declare no conflict of interest.

\section{References}

1. Mao, L.; Jin, H.; Wang, M.; Hu, Y.; Chen, S.; He, Q.; Chang, J.; Hong, C.; Zhou, Y.; Wang, D.; et al. Neurologic Manifestations of Hospitalized Patients With Coronavirus Disease 2019 in Wuhan, China. JAMA Neurol. 2020, 77, 683. [CrossRef] [PubMed]

2. Baig, A.M.; Khaleeq, A.; Ali, U.; Syeda, H. Evidence of the COVID-19 Virus Targeting the CNS: Tissue Distribution, Host-Virus Interaction, and Proposed Neurotropic Mechanisms. ACS Chem. Neurosci. 2020, 11, 995-998. [CrossRef] [PubMed]

3. Wu, Y.; Xu, X.; Chen, Z.; Duan, J.; Hashimoto, K.; Yang, L.; Liu, C.; Yang, C. Nervous system involvement after infection with COVID-19 and other coronaviruses. Brain Behav. Immun. 2020, 87, 18-22. [CrossRef] [PubMed]

4. Paterson, R.W.; Brown, R.L.; Benjamin, L.; Nortley, R.; Wiethoff, S.; Bharucha, T.; Jayaseelan, D.L.; Kumar, G.; Raftopoulos, R.E.; Zambreanu, L.; et al. The emerging spectrum of COVID-19 neurology: Clinical, radiological and laboratory findings. Brain 2020, 8, awaa240. [CrossRef]

5. Koralnik, I.J.; Tyler, K.L. COVID -19: A Global Threat to the Nervous System. Ann. Neurol. 2020, 88, 1-11. [CrossRef] [PubMed]

6. Bohmwald, K.; Gálvez, N.M.S.; Ríos, M.; Kalergis, A.M. Neurologic Alterations Due to Respiratory Virus Infections. Front. Cell. Neurosci. 2018, 12, 386. [CrossRef] [PubMed]

7. Montalvan, V.; Lee, J.; Bueso, T.; De Toledo, J.; Rivas, K. Neurological manifestations of COVID-19 and other coronavirus infections: A systematic review. Clin. Neurol. Neurosurg. 2020, 194, 105921. [CrossRef] [PubMed]

8. Li, Z.; Liu, T.; Yang, N.; Han, D.; Mi, X.; Li, Y.; Liu, K.; Vuylsteke, A.; Xiang, H.; Guo, X. Neurological manifestations of patients with COVID-19: Potential routes of SARS-CoV-2 neuroinvasion from the periphery to the brain. Front. Med. 2020, 1-9. [CrossRef]

9. Atluri, V.S.R.; Hidalgo, M.; Samikkannu, T.; Kurapati, K.R.V.; Nair, M.P.N. Synaptic Plasticity and Neurological Disorders in Neurotropic Viral Infections. Neural Plast. 2015, 2015, 1-14. [CrossRef]

10. Dong, Y.; Mo, X.; Hu, Y.; Qi, X.; Jiang, F.; Jiang, Z.; Tong, S. Epidemiology of COVID-19 among Children in China. Pediatrics 2020, 145, e20200702. [CrossRef]

11. Wu, Z.; McGoogan, J.M. Characteristics of and Important Lessons From the Coronavirus Disease 2019 (COVID-19) Outbreak in China. JAMA 2020, 323, 1239. [CrossRef] [PubMed]

12. Tezer, H.; Demirdağ, T.B. Novel coronavirus disease (COVID-19) in children. Turk. J. Med Sci. 2020, 50, 592-603. [CrossRef] [PubMed]

13. Zimmermann, P.; Curtis, N. Coronavirus Infections in Children Including COVID-19. Pediatr. Infect. Dis. J. 2020, 39, 355-368. [CrossRef] [PubMed]

14. Brodin, P. Why is COVID-19 so mild in children. Acta Paediatr. 2020, 109, 1082-1083. [CrossRef] [PubMed]

15. Baig, A.M. Neurological manifestations in COVID-19 caused by SARS-CoV-2. CNS Neurosci. Ther. 2020, 26, 499-501. [CrossRef] [PubMed]

16. Simon, A.K.; Holländer, G.A.; McMichael, A.J. Evolution of the immune system in humans from infancy to old age. Proc. R. Soc. B Biol. Sci. 2015, 282, 20143085. [CrossRef]

17. Sposato, B.; Scalese, M. Why do children seem to be more protected against COVID-19? A hypothesis. Med. Hypotheses 2020, 143, 110151. [CrossRef]

18. Zhu, L.Q.; Lu, X.; Chen, L. Possible causes for decreased susceptibility of children to coronavirus. Pediatr. Res. 2020, 1-3. [CrossRef]

19. Zimmermann, P.; Curtis, N. COVID-19 in Children, Pregnancy and Neonates. Pediatr. Infect. Dis. J. 2020, 39, 469-477. [CrossRef] 
20. Verdoni, L.; Mazza, A.; Gervasoni, A.; Martelli, L.; Ruggeri, M.; Ciuffreda, M.; Bonanomi, E.; D'Antiga, L. An outbreak of severe Kawasaki-like disease at the Italian epicentre of the SARS-CoV-2 epidemic: An observational cohort study. Lancet 2020, 395, 1771-1778. [CrossRef]

21. Riphagen, S.; Gomez, X.; Gonzalez-Martinez, C.; Wilkinson, N.; Theocharis, P. Hyperinflammatory shock in children during COVID-19 pandemic. Lancet 2020, 395, 1607-1608. [CrossRef]

22. Sisman, J.; Jaleel, M.A.; Moreno, W.; Rajaram, V.; Collins, R.R.; Savani, R.C.; Rakheja, D.; Evans, A.S. Intrauterine transmission of sars-cov-2 infection in a preterm infant. Pediatr. Infect. Dis. J. 2020, 39, 2265-2267. [CrossRef] [PubMed]

23. Kirtsman, M.; Diambomba, Y.; Poutanen, S.M.; Malinowski, A.K.; Vlachodimitropoulou, E.; Parks, W.T.; Erdman, L.; Morris, S.K.; Shah, P.S. Probable congenital SARS-CoV-2 infection in a neonate born to a woman with active SARS-CoV-2 infection. Can. Med. Assoc. J. 2020, 192, E647-E650. [CrossRef] [PubMed]

24. Vivanti, A.J.; Vauloup-Fellous, C.; Prevot, S.; Zupan, V.; Suffee, C.; Cao, J.D.; Benachi, A.; De Luca, D. Transplacental transmission of SARS-CoV-2 infection. Nat. Commun. 2020, 11, 3572. [CrossRef] [PubMed]

25. Chen, H.; Guo, J.; Wang, C.; Luo, F.; Yu, X.; Zhang, W.; Li, J.; Zhao, D.; Xu, D.; Gong, Q.; et al. Clinical characteristics and intrauterine vertical transmission potential of COVID-19 infection in nine pregnant women: A retrospective review of medical records. Lancet 2020, 395, 809-815. [CrossRef]

26. Zhang, L.; Dong, L.; Ming, L.; Wei, M.; Li, J.; Hu, R.; Yang, J. Severe acute respiratory syndrome coronavirus 2(SARS-CoV-2) infection during late pregnancy: A report of 18 patients from Wuhan, China. BMC Pregnancy Childbirth 2020, 20, 1-7. [CrossRef] [PubMed]

27. Zeng, L.; Xia, S.; Yuan, W.; Yan, K.; Xiao, F.; Shao, J.; Zhou, W. Neonatal Early-Onset Infection With SARS-CoV-2 in 33 Neonates Born to Mothers With COVID-19 in Wuhan, China. JAMA Pediatr. 2020. [CrossRef] [PubMed]

28. Liu, W.; Wang, J.; Li, W.; Zhou, Z.; Liu, S.; Rong, Z. Clinical characteristics of 19 neonates born to mothers with COVID-19. Front. Med. 2020, 14, 193-198. [CrossRef]

29. Schwartz, D.A. An Analysis of 38 Pregnant Women with COVID-19, Their Newborn Infants, and Maternal-Fetal Transmission of SARS-CoV-2: Maternal Coronavirus Infections and Pregnancy Outcomes. Arch. Pathol. Lab. Med. 2020, 144, 799-805. [CrossRef]

30. Lu, Q.; Shi, Y. Coronavirus disease (COVID-19) and neonate: What neonatologist need to know. J. Med. Virol. 2020, 92, 564-567. [CrossRef]

31. Salvatore, C.M.; Han, J.-Y.; Acker, K.P.; Tiwari, P.; Jin, J.; Brandler, M.; Cangemi, C.; Gordon, L.; Parow, A.; DiPace, J.; et al. Neonatal management and outcomes during the COVID-19 pandemic: An observation cohort study. Lancet Child Adolesc. Health 2020, 2352. [CrossRef]

32. Wei, M.; Yuan, J.; Liu, Y.; Fu, T.; Yu, X.; Zhang, Z.-J. Novel Coronavirus Infection in Hospitalized Infants Under 1 Year of Age in China. JAMA 2020, 323, 1313. [CrossRef] [PubMed]

33. Piersigilli, F.; Carkeek, K.; Hocq, C.; Van Grambezen, B.; Hubinont, C.; Chatzis, O.; Van Der Linden, D.; Danhaive, O. COVID-19 in a 26-week preterm neonate. Lancet Child Adolesc. Heal. 2020, 4, 476-478. [CrossRef]

34. Mehan, A.; Venkatesh, A.; Girish, M. COVID-19 in pregnancy: Risk of adverse neonatal outcomes. J. Med. Virol. 2020. [CrossRef] [PubMed]

35. Abdoli, A.; Falahi, S.; Kenarkoohi, A.; Shams, M.; Mir, H.; Jahromi, M.A.M. The COVID-19 pandemic, psychological stress during pregnancy, and risk of neurodevelopmental disorders in offspring: A neglected consequence. J. Psychosom. Obstet. Gynecol. 2020, 1-2. [CrossRef]

36. Li, Q. Psychosocial and coping responses towards 2019 coronavirus diseases (COVID-19): A cross-sectional study within the Chinese general population. QJM 2020, 17, hcaa226. [CrossRef]

37. Berthelot, N.; Lemieux, R.; Garon-Bissonnette, J.; Drouin-Maziade, C.; Martel, É.; Maziade, M. Uptrend in distress and psychiatric symptomatology in pregnant women during the coronavirus disease 2019 pandemic. Acta Obstet. Gynecol. Scand. 2020, 99, 848-855. [CrossRef] [PubMed]

38. Jiao, W.Y.; Na Wang, L.; Liu, J.; Fang, S.F.; Jiao, F.Y.; Pettoello-Mantovani, M.; Somekh, E. Behavioral and Emotional Disorders in Children during the COVID-19 Epidemic. J. Pediatr. 2020, 221, 264. [CrossRef]

39. Lackey, K.A.; Pace, R.M.; Williams, J.E.; Bode, L.; Donovan, S.M.; Järvinen, K.M.; Seppo, A.E.; Raiten, D.J.; Meehan, C.L.; McGuire, M.A.; et al. SARS-CoV-2 and human milk: What is the evidence. Matern. Child Nutr. 2020, e13032. [CrossRef] 
40. Mimouni, F.; Lakshminrusimha, S.; Pearlman, S.A.; Raju, T.; Gallagher, P.G.; Mendlovic, J. Perinatal aspects on the covid-19 pandemic: A practical resource for perinatal-neonatal specialists. J. Perinatol. 2020, 40, 820-826. [CrossRef]

41. Puopolo, K.M.; Hudak, M.L.; Kimberlin, D.W.; Cummings, J. Initial Guidance: Management of Infants Born to Mothers with COVID-19; American Academy of Pediatrics Committee on Fetus and Newborn, Section on Neonatal Perinatal Medicine, and Commitee on Infectious Diseases: Washington, DC, USA, 2020.

42. Chen, D.; Yang, H.; Cao, Y.; Cheng, W.; Duan, T.; Fan, C.; Fan, S.; Feng, L.; Gao, Y.; He, F.; et al. Expert consensus for managing pregnant women and neonates born to mothers with suspected or confirmed novel coronavirus ( COVID -19) infection. Int. J. Gynecol. Obstet. 2020, 149, 130-136. [CrossRef] [PubMed]

43. Asadi-Pooya, A.A.; Simani, L. Central nervous system manifestations of COVID-19: A systematic review. J. Neurol. Sci. 2020, 413, 116832. [CrossRef] [PubMed]

44. Needham, E.J.; Chou, S.H.-Y.; Coles, A.J.; Menon, D.K. Neurological Implications of COVID-19 Infections. Neurocrit. Care 2020, 32, 667-671. [CrossRef] [PubMed]

45. Paybast, S.; Emami, A.; Koosha, M.; Baghalha, F. Novel Coronavirus Disease (COVID-19) and Central Nervous System Complications: What Neurologist Need to Know. Acta Neurol. Taiwan 2020, 29, $24-31$. [PubMed]

46. Helms, J.; Kremer, S.; Merdji, H.; Clere-Jehl, R.; Schenck, M.; Kummerlen, C.; Collange, O.; Boulay, C.; Fafi-Kremer, S.; Ohana, M.; et al. Neurologic features in severe SARS-CoV-2 infection. N. Engl. J. Med. 2020, 382, 2268-2270. [CrossRef] [PubMed]

47. Khan, S.; Gomes, J. Neuropathogenesis of SARS-CoV-2 infection. Elife 2020, 9, 59136. [CrossRef] [PubMed]

48. Oxley, T.J.; Mocco, J.; Majidi, S.; Kellner, C.P.; Shoirah, H.; Singh, I.P.; De Leacy, R.A.; Shigematsu, T.; Ladner, T.R.; Yaeger, K.A.; et al. Large-Vessel Stroke as a Presenting Feature of Covid-19 in the Young. N. Engl. J. Med. 2020, 382, e60. [CrossRef]

49. Beyrouti, R.E.; Adams, M.; Benjamin, L.; Cohen, H.; Farmer, S.F.; Goh, Y.Y.; Humphries, F.; Jäger, H.R.A.; Losseff, N.; Perry, R.J.; et al. Characteristics of ischaemic stroke associated with COVID-19. J. Neurol. Neurosurg. Psychiatry 2020, 91, 889-891. [CrossRef]

50. Christy, A. COVID-19: A Review for the Pediatric Neurologist. J. Child Neurol. 2020. [CrossRef]

51. Pilotto, A.; Odolini, S.; Masciocchi, S.S.; Comelli, A.; Volonghi, I.; Gazzina, S.; Nocivelli, S.; Pezzini, A.; Focà, E.; Caruso, A.; et al. Steroid-Responsive Encephalitis in Coronavirus Disease 2019. Ann. Neurol. 2020, 88, 423-427. [CrossRef]

52. Von Weyhern, C.H.; Kaufmann, I.; Neff, F.; Kremer, M. Early evidence of pronounced brain involvement in fatal COVID-19 outcomes. Lancet 2020, 395, e109. [CrossRef]

53. Solomon, I.H.; Normandin, E.; Bhattacharyya, S.; Mukerji, S.S.; Keller, K.; Ali, A.S.; Adams, G.; Hornick, J.L.; Padera, R.F.; Sabeti, P. Neuropathological Features of Covid-19. N. Engl. J. Med. 2020. [CrossRef] [PubMed]

54. Schaller, T.; Hirschbühl, K.; Burkhardt, K.; Braun, G.; Trepel, M.; Märkl, B.; Claus, R. Postmortem Examination of Patients With COVID-19. JAMA 2020, 323, 2518. [CrossRef] [PubMed]

55. Sohal, S.; Mansur, M.; Mossammat, M. COVID-19 Presenting with Seizures. IDCases 2020, 20 , e00782. [CrossRef] [PubMed]

56. Kuroda, N. Epilepsy and COVID-19: Associations and important considerations. Epilepsy Behav. 2020, 108, 107122. [CrossRef] [PubMed]

57. Galanopoulou, A.S.; Ferastraoaru, V.; Correa, D.J.; Cherian, K.; Duberstein, S.; Gursky, J.; Hanumanthu, R.; Hung, C.; Molinero, I.; Khodakivska, O.; et al. EEG findings in acutely ill patients investigated for SARS-CoV-2/COVID-19: A small case series preliminary report. Epilepsia Open 2020, 5, 314-324. [CrossRef] [PubMed]

58. Petrescu, A.-M.; Taussig, D.; Bouilleret, V. Electroencephalogram (EEG) in COVID-19: A systematic retrospective study. Neurophysiol. Clin. Neurophysiol. 2020, 50, 155-165. [CrossRef]

59. Poncet-Megemont, L.; Paris, P.; Tronchere, A.; Salazard, J.; Pereira, B.; Dallel, R.; Aumeran, C.; Beytout, J.; Jacomet, C.; Laurichesse, H.; et al. High Prevalence of Headaches During Covid-19 Infection: A Retrospective Cohort Study. Headache J. Head Face Pain 2020. [CrossRef]

60. Gane, S.B.; Kelly, C.; Hopkins, C. Isolated sudden onset anosmia in COVID-19 infection. A novel syndrome. Rhinology 2020, 58, 299-301. [CrossRef]

61. Sedaghat, A.R.; Gengler, I.; Speth, M.M. Olfactory Dysfunction: A Highly Prevalent Symptom of COVID-19 with Public Health Significance. Otolaryngol. Neck Surg. 2020, 163, 12-15. [CrossRef] 
62. Cooper, K.W.; Brann, D.H.; Farruggia, M.C.; Bhutani, S.; Pellegrino, R.; Tsukahara, T.; Weinreb, C.; Joseph, P.V.; Larson, E.D.; Parma, V.; et al. COVID-19 and the Chemical Senses: Supporting Players Take Center Stage. Neuron 2020, 107, 219-233. [CrossRef]

63. Mak, P.Q.; Chung, K.-S.; Wong, J.S.-C.; Shek, C.-C.; Kwan, M.Y.-W. Anosmia and Ageusia: Not an Uncommon Presentation of COVID-19 Infection in Children and Adolescents. Pediatr. Infect. Dis. J. 2020, 39, e199-e200. [CrossRef] [PubMed]

64. Alberti, P.; Beretta, S.; Piatti, M.; Karantzoulis, A.; Piatti, M.L.; Santoro, P.; Viganò, M.; Giovannelli, G.; Pirro, F.; Montisano, D.A.; et al. Guillain-Barré syndrome related to COVID-19 infection. Neurol. Neuroimmunol. Neuroinflamm. 2020, 7, e741. [CrossRef] [PubMed]

65. Dalakas, M.C. Guillain-Barré syndrome: The first documented COVID-19-triggered autoimmune neurologic disease. Neurol. Neuroimmunol. Neuroinflamm. 2020, 7, e781. [CrossRef] [PubMed]

66. Khalifa, M.; Zakaria, F.; Ragab, Y.; Saad, A.; Bamaga, A.; Emad, Y.; Rasker, J.J. Guillain-Barré syndrome associated with severe accute respiratory syndrome coronoavirus 2 detection and coronavirus disease 2019 in a child. J. Pediatr. Infect. Dis. Soc. 2020, 11, piaa086. [CrossRef]

67. Frank, C.H.M.; Almeida, T.V.R.; Marques, E.A.; de Sousa Monteiro, Q.; Feitoza, P.V.S.; Borba, M.G.S.; Vasconcelos, H.L.; de Souza Bastos, M.; Lacerda, M.V.G. Guillain-Barré syndrome associated with SARS-CoV-2 infection in a pediatric patient. J. Trop. Pediatr. 2020, 12, fmaa044. [CrossRef]

68. Boziki, M.K.; Mentis, A.-F.A.; Shumilina, M.; Makshakov, G.; Evdoshenko, E.; Grigoriadis, N. COVID-19 Immunopathology and the Central Nervous System: Implication for Multiple Sclerosis and Other Autoimmune Diseases with Associated Demyelination. Brain Sci. 2020, 10, 345. [CrossRef]

69. Berger, J.R.; Brandstadter, R.; Bar-Or, A. COVID-19 and MS disease-modifying therapies. Neurol. Neuroimmunol. Neuroinflamm. 2020, 7, e761. [CrossRef]

70. De Rose, D.; Piersigilli, F.; Ronchetti, M.P.; Santisi, A.; Bersani, I.; Dotta, A.; Danhaive, O.; Auriti, C. The Study Group of Neonatal Infectious Diseases of The Italian Society of Neonatology (SIN); Novel Coronavirus disease (COVID-19) in newborns and infants: What we know so far. Ital. J. Pediatr. 2020, 46, 1-8. [CrossRef]

71. Nathan, N.; Prevost, B.; Corvol, H. Atypical presentation of COVID-19 in young infants. Lancet 2020, 395, 1481. [CrossRef]

72. Chacón-Aguilar, R.; Osorio-Cámara, J.M.; Sanjurjo-Jimenez, I.; González-González, C.; López-Carnero, J.; Pérez-Moneo-Agapito, B. COVID-19: Fever syndrome and neurological symptoms in a neonate. An. Pediatr (English Edition) 2020, 92, 373-374. [CrossRef]

73. Lorenz, N.; Treptow, A.; Schmidt, S.; Hofmann, R.; Raumer-Engler, M.; Heubner, G.; Gröber, K. Neonatal Early-Onset Infection With SARS-CoV-2 in a Newborn Presenting With Encephalitic Symptoms. Pediatr. Infect. Dis. J. 2020. [CrossRef] [PubMed]

74. Dugue, R.; Cay-Martínez, K.C.; Thakur, K.T.; Garcia, J.A.; Chauhan, L.V.; Williams, S.H.; Briese, T.; Jain, K.; Foca, M.; McBrian, D.K.; et al. Neurologic manifestations in an infant with COVID-19. Neurology 2020, 94, 1100-1102. [CrossRef] [PubMed]

75. Bhatta, S.; Sayed, A.; Ranabhat, B.; Bhatta, R.K.; Acharya, Y. New-Onset Seizure as the Only Presentation in a Child With COVID-19. Cureus 2020. [CrossRef]

76. Nakra, N.A.; Blumberg, D.A.; Herrera-Guerra, A.; Lakshminrusimha, S. Multi-System Inflammatory Syndrome in Children (MIS-C) Following SARS-CoV-2 Infection: Review of Clinical Presentation, Hypothetical Pathogenesis, and Proposed Management. Children 2020, 7, 69. [CrossRef]

77. Chiotos, K.; Bassiri, K.C.H.; Behrens, E.M.; Blatz, A.M.; Chang, J.; Diorio, C.; Fitzgerald, J.C.; Topjian, A.; Odom John, A.R. Multisystem inflammatory syndrome in children during the COVID-19 pandemic: A case series. J. Pediatr. Infect. Dis. Soc. 2020, 13, 393-398. [CrossRef]

78. Whittaker, E.; Bamford, A.; Kenny, J.; Kaforou, M.; Jones, C.E.; Shah, P.; Ramnarayan, P.; Fraisse, A.; Miller, O.; Davies, P.; et al. Clinical Characteristics of 58 Children With a Pediatric Inflammatory Multisystem Syndrome Temporally Associated With SARS-CoV-2. JAMA 2020. [CrossRef]

79. Toubiana, J.; Poirault, C.; Corsia, A.; Bajolle, F.; Fourgeaud, J.; Angoulvant, F.; Debray, A.; Basmaci, R.; Salvador, E.; Biscardi, S.; et al. Kawasaki-like multisystem inflammatory syndrome in children during the covid-19 pandemic in Paris, France: Prospective observational study. BMJ 2020, 369, m2094. [CrossRef]

80. Feldstein, L.R.; Rose, E.B.; Horwitz, S.M.; Collins, J.P.; Newhams, M.M.; Son, M.B.F.; Newburger, J.W.; Kleinman, L.C.; Heidemann, S.M.; Martin, A.A.; et al. Multisystem Inflammatory Syndrome in U.S. Children and Adolescents. N. Engl. J. Med. 2020. [CrossRef] 
81. Abdel-Mannan, O.; Eyre, M.; Löbel, U.; Bamford, A.; Eltze, C.; Hameed, B.; Hemingway, C.; Hacohen, Y. Neurologic and Radiographic Findings Associated With COVID-19 Infection in Children. JAMA Neurol. 2020. [CrossRef]

82. Kontzialis, M.; Soares, B.P.; Huisman, T.A. Lesions in the Splenium of the Corpus Callosum on MRI in Children: A Review. J. Neuroimaging 2017, 27, 549-561. [CrossRef] [PubMed]

83. Abrams, J.Y.; Godfred-Cato, S.E.; Oster, M.E.; Chow, E.J.; Koumans, E.H.; Bryant, B.; Leung, J.W.; Belay, E.D. Multisystem Inflammatory Syndrome in Children (MIS-C) Associated with SARS-CoV-2: A Systematic Review. J. Pediatr. 2020, 22. [CrossRef] [PubMed]

84. Iroegbu, J.D.; Ifenatuoha, C.W.; Ijomone, O.M. Potential neurological impact of coronaviruses: Implications for the novel SARS-CoV-2. Neurol. Sci. 2020, 41, 1329-1337. [CrossRef] [PubMed]

85. Sungnak, W.; Network, H.L.B.; Huang, N.; Bécavin, C.; Berg, M.; Queen, R.; Litvinukova, M.; Talavera-López, C.; Maatz, H.; Reichart, D.; et al. SARS-CoV-2 entry factors are highly expressed in nasal epithelial cells together with innate immune genes. Nat. Med. 2020, 26, 681-687. [CrossRef] [PubMed]

86. Schett, G.; Sticherling, M.; Neurath, M.F. COVID-19: Risk for cytokine targeting in chronic inflammatory diseases. Nat. Rev. Immunol. 2020, 20, 271-272. [CrossRef] [PubMed]

87. Coperchini, F.; Chiovato, L.; Croce, L.; Magri, F.; Rotondi, M. The cytokine storm in COVID-19: An overview of the involvement of the chemokine/chemokine-receptor system. Cytokine Growth Factor Rev. 2020, 53, $25-32$. [CrossRef]

88. Channappanavar, R.; Perlman, S. Pathogenic human coronavirus infections: Causes and consequences of cytokine storm and immunopathology. Semin. Immunopathol. 2017, 39, 529-539. [CrossRef]

89. Kempuraj, D.; Selvakumar, G.P.; Ahmed, M.E.; Raikwar, S.P.; Thangavel, R.; Khan, A.; Zaheer, S.A.; Iyer, S.S.; Burton, C.; James, D.; et al. COVID-19, Mast Cells, Cytokine Storm, Psychological Stress, and Neuroinflammation. Neuroscience 2020, 1-13. [CrossRef]

90. Jiang, N.M.; Cowan, M.; Moonah, S.N.; Petri, W.A. The Impact of Systemic Inflammation on Neurodevelopment. Trends Mol. Med. 2018, 24, 794-804. [CrossRef]

91. Nye, S.; Whitley, R.J.; Kong, M.Y.F. Viral Infection in the Development and Progression of Pediatric Acute Respiratory Distress Syndrome. Front. Pediatr. 2016, 4, 128. [CrossRef]

92. South, A.M.; Brady, T.M.; Flynn, J.T. ACE2, COVID-19, and ACE inhibitor and ARB use during the pandemic: The pediatric perspective. Hypertension 2020, 76, 16-22. [CrossRef] [PubMed]

93. Mendoza, E.J.; Manguiat, K.; Wood, H.; Derbot, M. Two detailed plaque assay protocols for the quantification of infectious SARS-CoV-2. Curr. Protoc. Microbiol. 2020, 57, 105. [CrossRef] [PubMed]

94. Desforges, M.; Le Coupanec, A.; Stodola, J.K.; Meessen-Pinard, M.; Talbot, P.J. Human coronaviruses: Viral and cellular factors involved in neuroinvasiveness and neuropathogenesis. Virus Res. 2014, 194, 145-158. [CrossRef] [PubMed]

95. Netland, J.; Meyerholz, D.K.; Moore, S.A.; Cassell, M.; Perlman, S. Severe Acute Respiratory Syndrome Coronavirus Infection Causes Neuronal Death in the Absence of Encephalitis in Mice Transgenic for Human ACE2. J. Virol. 2008, 82, 7264-7275. [CrossRef] [PubMed]

96. Natoli, S.; Oliveira, V.; Calabresi, P.; Maia, L.F.; Pisani, A. Does SARS-Cov-2 invade the brain? Translational lessons from animal models. Eur. J. Neurol. 2020. [CrossRef] [PubMed]

97. Yuan, L.; Tang, Q.; Cheng, T.; Xia, N. Animal models for emerging coronavirus: Progress and new insights. Emerg. Microbes Infect. 2020, 9, 949-961. [CrossRef]

98. Sellner, J. Of mice and men: COVID-19 challenges translational neuroscience. Eur. J. Neurol. 2020. [CrossRef]

99. Yazdanpanah, N.; Saghazadeh, A.; Rezaei, N. Anosmia: A Missing Link in the Neuroimmunology of Coronavirus Disease 2019 (COVID-19). Rev. Neurosci. 2020, 1. Available online: 10:/j/revneuro.ahead-ofprint/revneuro-2020-0039/revneuro-2020-0039.xml (accessed on 10 August 2020). [CrossRef]

100. Chen, M.; Shen, W.; Rowan, N.R.; Kulaga, H.; Hillel, A.; Jr, M.R.; Lane, A.P. Elevated ACE2 expression in the olfactory neuroepithelium: Implications for anosmia and upper respiratory SARS-CoV-2 entry and replication. Eur. Respir. J. 2020, 2001948. [CrossRef]

101. Jacomy, H.; Fragoso, G.; Almazan, G.; Mushynski, W.E.; Talbot, P.J. Human coronavirus OC43 infection induces chronic encephalitis leading to disabilities in BALB/C mice. Virology 2006, 349, 335-346. [CrossRef]

102. Li, Y.-C.; Bai, W.-Z.; Hashikawa, T. The neuroinvasive potential of SARS-CoV2 may play a role in the respiratory failure of COVID-19 patients. J. Med. Virol. 2020, 92, 552-555. [CrossRef] [PubMed] 
103. Lamouroux, A.; Attie-Bitach, T.; Martinovic, J.; Leruez-Ville, M.; Yves, V. Evidence for and against vertical transmission for severe acute respiratory syndrome coronavirus 2. Am. J. Obstet. Gynecol. 2020, 223, 91.e1-91.e4. [CrossRef] [PubMed]

104. Obermeier, B.; Daneman, R.; Ransohoff, R.M. Development, maintenance and disruption of the blood-brain barrier. Nat. Med. 2013, 19, 1584-1596. [CrossRef] [PubMed]

105. Goasdoue, K.; Miller, S.M.; Colditz, P.B.; Björkman, S.T. Review: The blood-brain barrier; protecting the developing fetal brain. Placenta 2017, 54, 111-116. [CrossRef] [PubMed]

106. Bostanciklioğlu, M. SARS-CoV2 entry and spread in the lymphatic drainage system of the brain. Brain Behav. Immun. 2020, 87, 122-123. [CrossRef] [PubMed]

107. Takayama, K. In Vitro and Animal Models for SARS-CoV-2 research. Trends Pharmacol. Sci. 2020, 41, 513-517. [CrossRef]

108. Gandhi, S.; Srivastava, A.K.; Ray, U.; Tripathi, P.P. Is the Collapse of the Respiratory Center in the Brain Responsible for Respiratory Breakdown in COVID-19 Patients. ACS Chem. Neurosci. 2020, 11, 1379-1381. [CrossRef]

109. Cave, E. COVID-19 Super-spreaders: Definitional Quandaries and Implications. Asian Bioeth. Rev. 2020, 12, 235-242. [CrossRef]

110. Rubin, M.A.; Bonnie, R.J.; Epstein, L.; Hemphill, C.; Kirschen, M.; Lewis, A.; Suarez, J.I. Ethics, Law, and Humanities Committee, a joint committee of the American Academy of Neurology, American Neurological Association, and Child Neurology Society; in collaboration with the Neurocritical Care Society Ethics Committee AAN position statement. Neurology 2020, 95, 167-172. [CrossRef]

111. Condie, L.O. Neurotropic mechanisms in COVID-19 and their potential influence on neuropsychological outcomes in children. Child Neuropsychol. 2020, 26, 1-20. [CrossRef]

(C) 2020 by the authors. Licensee MDPI, Basel, Switzerland. This article is an open access article distributed under the terms and conditions of the Creative Commons Attribution (CC BY) license (http://creativecommons.org/licenses/by/4.0/). 